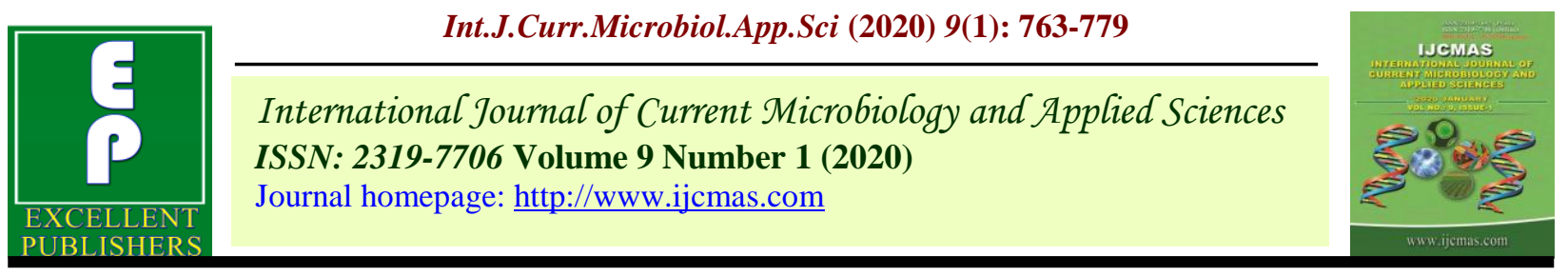

Review Article

https://doi.org/10.20546/ijcmas.2020.901.083

\title{
Biofortification to Improve Nutrition: A Review
}

\author{
Neha Agrawal*, Priyanka Upadhyay and Santosh B. Tigadi
}

Punjab Agricultural University, Ludhiana, Punjab, India, 141004

*Corresponding author

\section{A B S T R A C T}

\section{Keywords}

Biofortification, Nutrition, Breeding, Transgenic,

Agronomic, Genetic modification, Micronutrients

\section{Article Info}

Accepted:

15 December 2019 Available Online: 20 January 2020
Biofortification is a promising, economical, and sustainable technique of providing micronutrients. It primarily targets population that has mainly dependent upon major food crops which are unfortunately poor sources of micronutrients. In developing countries, more than 20 million farm families are now growing and consuming biofortified crops. Here we described history of Biofortification, it's three different methods namely transgenic, breeding and agronomic and efforts to review different Biofortification research. Biofortification research based on different nutrient, different strategies and conducted on different crops. Address advantages and disadvantages of Biofortification and quote that besides challenges biofortified crop embrace bright future to challenge malnutrition.

\section{Introduction}

"Biofortification" refers to enhanced nutrition in food crops with increased bioavailability to the human that are developed and grown by using transgenic techniques, conventional plant breeding, or agronomic practices. Micronutrient deficiencies leads to hidden hunger which distress more than two billion individuals, or one in three people, globally (FAO et al., 2015). These deficiencies occur when intake and absorption of vitamins and minerals are in adequate to sustain decent health and development (Hodge 2016, Sumithra et al., 2013). In past 50 years, agricultural research for developing countries has only increased production however, the production of micronutrient-rich non-staples, such as vegetables, pulses and animal products, has not increased in equal measure (Gould, 2017). Now agriculture is enduring a shift from producing quantity of food crops to producing nutrient-rich food crops in sufficient quantities. This will help in fighting "hidden hunger" especially in poor and developing countries, where diets are subject to micronutrient-poor staple food crops (Khush et al., 2012).

In short term, providing biofortified crops can help to address micronutrient deficiencies by increasing the daily adequacy of 
micronutrient intakes among individuals (Bouis et al., 2011) through supplementation programme by international health organization. However these organizations are dependent on external funding which is not guaranteed every year. Other limitations are high cost of biofortified food; it's availability to markets and health-care systems, and lack of awareness regarding long-term health benefits of these nutrient supplements (Gilani and Nasim 2007, Rudkowska 2013). Hence, biofortification of different crop varieties offers a sustainable and long-term solution in providing micronutrients-rich crops to people. Economically, biofortification is a one-time investment and offers long-term cost benefit with sustainable means for fighting hidden hunger, as buying biofortified crops include no costs compare to buying the fortificants and adding them to the food supply during processing (Bouis1999, Nestel et al., 2006 and Pfeiffer and McClafferty 2007). Biofortified crops are also a feasible means of reaching rural populations who may have limited access to diverse diets or other micronutrient interventions. Target micronutrient levels for biofortified crops are set to meet the specific dietary needs of women and children, based on existing consumption patterns. Retention of micronutrients in crops is measure under typical processing, storage, and cooking practices to make sure that sufficient amount of vitamins and minerals will remain in foods eaten by target populations. Along with retention, absorption is also prerequisite for biofortifiedcrops.

\section{History of biofortification}

Biofortification concept has been started from the time of Green Revolution (1966-1985) (Pingali, 2012). An American economist named Howarth E "Howdy" Bouis started working on solution for micronutrient malnutrition in the early 1990s. Earlier, experts considered calorie intake as standard however research carried out by Bouis and Lawrence Haddad in 1984 to 1990 shown that mineral and vitamin intake was the primary constraint of improving nutrition outcomes and reducing micronutrient deficiencies. Steve Beebe, in 2001 coined the term 'Biofortification'. In the succeeding years, higher amounts of funding were secured by Bouis. In 2003, CGIAR's Biofortification Challenge Program was renamed as Harvest Plus (Harvest Plus 2018) till 2008, target populations were recognized andproof-ofconcept research was conducted. In 2013, the first biofortified crops were bredand approved for release by national varietal release committees and nutritional efficacy trials were carried out. Since 2014, thedelivery of biofortified crops has been improved and more than 140 varieties of ten crops that are biofortified with pro-vitamin A, iron and/or zinc have been released in 30 different countries. In some countries, just one biofortified crop is being used but in others, such as Brazil, India and China, several are used in what is known as a 'food basket' approach. In 2016, Bouis was awarded by the World Food Prize for his groundbreaking work on Biofortification.

\section{Biofortification necessities}

Human beings need around forty known nutrients in adequate amounts to live healthy lives. The nutrients required in very small amounts in the human body are termed as micronutrients-namely iron, zinc, copper, manganese, iodine, selenium, molybdenum, cobalt, nickel, and vitamin A while the other class of essential mineral elements which is required in small quantity includes - sodium, potassium, calcium, magnesium, phosphorous, chlorine, and sulfur (Prashanth et al., 2015). Together, these nutrients play crucial roles in human's physical and mental development (Guo et al., 2015). 
Micronutrients regulate important functions and metabolic processes in our body by acting as cofactors for the functioning of various enzymes in the human body (Welch and Graham, 2004). Agricultural products such as rice, wheat, cassava, and maize are the primary source of nutrients especially for those living in developing countries (Graham et al., 2001, McGuire 1993, Schneeman 2001). However, it contains insufficient amounts of several nutrients such as vitamin A, iron, zinc, calcium, manganese, copper, iodine, or selenium with respect to meeting daily requirements. Nutrient deficient food leads to unhealthy lives, sickness, disability, reduced development/ stunted growth/ childhood stunting, arrested mental and physical growth, diminished livelihoods, and reduced national socioeconomic development (Nishida et al., 2004, Branca and Ferrari, 2002; Golden, 1991; Grantham-McGregor and Ani, 1999; Ramakrishnam et al., 1999; Caballero, 2002). More than $30 \%$ of the world's population has been reported to be anemic(Stevens et al., 2013) and suffering from hidden hunger. Micronutrient deficiency affect about $38 \%$ of pregnant women and $43 \%$ of pre-school children worldwide. Evaluations have specified that almost half of this is attributed to iron deficiency (Yoon et al., 1997).

Iron nutrition research examined efficacy of biofortified iron bean and iron pearl millet. When these biofortified beans were given to iron-depleted university women, they showed a significant increase in hemoglobin and total body iron after 4.5 months (Haas et al., 2017). Similarly, secondary school iron-deficient adolescent boys and girls from Maharashtra, India showed significant improvement in serum ferritin and total body iron after consuming biofortified pearl millet flat bread twice daily for four months. Vitamin A bioavailability studies found efficient conversions from pro-vitamin A to retinol, the form of vitamin $A$ used by the body.
Efficiency studies confirmed that consumption of orange sweet potato (OSP) can result in significant increase in vitamin $\mathrm{A}$ among women and children of rural Uganda and found 9 percent decrease in low serum retinol (Haskell et al., 2004; Low et al., 2007; van Jaarsveld et al., 2005, Hotz et al., 2012). Biofortified pro-vitamin A maize found efficient source of vitamin A when consumed as a staple crop proved in study conducted at Zambia. Children with 5-7-year-old showed that total body vitamin $\mathrm{A}$ in the children consuming orange maize increased significantly compared with those in the control group (Gannon et al., 2014) and significantly improve visual function in marginally vitamin A deficient children (Palmer et al., 2016). Zinc in biofortified wheat is bioavailable (Rosado et al., 2009). A recent study showed that DNA strand breaks are a sensitive indicator of modest increases in zinc intake, such as the amount of additional zinc that might be delivered by a biofortifiedcrop (King et al., 2016). One more important point of attention is uneven distribution of the nutrients among different plant parts (Zhu et al., 2007). For example, the iron content is high in rice leaves, but low in polished rice grain. To one side from under nutrition, over nutrition leading to problems of overweight and in particular, high rate of diabetes is a matter of concern. Therefore, Biofortification is also directed toward enhancing the contents of desired micronutrients in the edible portion of crop plants.

\section{Different approaches for Biofortification}

The ultimate goal of Biofortification is producing nutritious and safe foods, sufficiently and sustainably (Saltzman 2013). Biofortification in crop plants can be achieved through three main approaches i.e. transgenic, conventional, and agronomic, by the use of biotechnology, crop breeding, and fertilization strategies, respectively. The crops 
targeted all three approaches include staple crops like rice, wheat, maize, sorghum, lupine, common bean, potato, sweet potato, and tomato. With two approaches i.e. transgenic and breeding cassava, cauliflower, and banana have been biofortified while transgene and agronomic approaches have been used in barley, soybean, lettuce, carrot, canola, and mustard. Oil seed Biofortification has been achieved through transgenic means only, because of limited availability of genetic diversity for the targeted component, low heritability, and linkage drag. Biofortification by breeding has been achieved in crops and specified components when genetic diversity is available in the utilizable form in the primary, secondary, or tertiary gene pool of the targeted crop. Transgenic-based approach has advantages that a useful gene once discovered, can be utilized for targeting multiple crops. It has been found that PSY, carotene desaturase, and lycopene $\beta$-cyclase for vitamins, ferritin and nicotinamine synthase for minerals, albumin for essential amino acids, and desaturase for essential fatty acids have been utilized in multiple events including multiple crops (Zhu et al., 2007, Brinch-Pedersen et al., 2007). Additionally when a certain micronutrient doesn't exist naturally in crops, transgenic approaches remain the only feasible option to fortify these crop with that particular nutrient (Rudkowska et al., 2013). Furthermore, pathways from bacteria and other organisms canalso be introduced into crops to exploit alternative pathways for metabolic engineering (NewellMcGloughlin 2008). In addition, genetic modifications can be targeted to redistribute micronutrients between tissues, enhance the micronutrient concentration in the edible portions of commercial crops, increasing the efficiency of biochemical pathways in edible tissues, or even the reconstruction of selected pathways (Shewmaker et al., 1999, Agrawal et al., 2005, Yang et al., 2002).

\section{Biofortification: Agronomic Approach}

Microminerals like Fe, $\mathrm{Zn}, \mathrm{Cu}, \mathrm{Mg}$, I, Se, Mo, $\mathrm{Co}$, and $\mathrm{Ni}$ exist in variable amount in different portion of plants and are typically absorbed from the soil. Improvement of the soil micronutrient status through agronomic approaches can temporarily improve the nutritional status of crops and can contribute to decrease in micronutrient deficiency in humans (Cakmak, 2008). It usually includes physical application of mineral fertilizers (Cakmak and Kutman, 2018) and increase in their mobilization and solubilization from the soil to edible parts of plants. In contrast with inorganic forms of minerals, the organic minerals are more accessible as they can be easily absorbed; less excreted (Daniels 1996) and has less toxic symptoms (DRI 2000). Like application of selenium complex salts as fertilizers helps in production seleniumenriched soybean (Yang, 2003).

Targeted application of soluble inorganic fertilizers to the roots or to the leaves are practiced, when crops are grown in soils, where mineral elements become immediately unavailable or not readily translocated to edible tissues. For example Biofortification of rice plants by foliar spray of iron and zinc proved an efficient way to promote iron and zinc concentration and its bioavailability in rice grains (He et al., 2013, Yuan et al., 2013, Fang et al., 2008, Wei et al., 2012, Boonchuay et al., 2013, Jiang et al., 2008, Hamidou et al., 2014, Shivay et al., 2008, Ram et al., 2016). While, fortifying germinating rice plantlets with ferrous sulfate lead to increase iron concentration in germinated brown rice (Yuan et al., 2013).Other experiments were undertaken using foliar zinc fertilizers which significantly increased zinc concentrations both in flesh and skin of tubers. Experiment also showed that zinc oxide and zinc sulfate were more effective than zinc nitrate as foliar fertilizers 
(White 2017). Targeted foliar zinc application also reduced human zinc deficiency in regions having zinc-deficient soil and improved its bioavailability by reducing ant nutrient factors like phytic acid (Yang et al., 2011). Selenium, which is an essential trace element for human health and proved to be a potent antioxidant, has been also increased by the application of selenate as a foliar spray or as fertilizer in rice (Fang et al., 2008, Chen et al., 2002, Ros et al., 2016, Premarathna et al., 2016, Xu and $\mathrm{Hu}$ 2004, Giacosa et al., 2014, Liu and Gu 2008) Increase in Se content of potato tubers has been reported after foliar application of selenium, selenite, and selenate to potato (Poggi et al., 2000, Cuderman et al., 2008). Lettuce I and Se biofortification have been achieved by the application of $\mathrm{KIO} 3$ and $\mathrm{Na} 2 \mathrm{SeO} 4$ as foliar spray and nutrient medium (Samolen et al., 2014).

Biofortification through agronomic means is easy and economical, however needs special attention for source of nutrient, application method and effects on the environment. It should be followed regularly in every crop season because of this it may be less costeffective in some cases. Some developed country is having an example of using mineral fertilizers successfully. Like, Se fertilization of crops in Finland (Aro et al., 1995), zinc fertilization in Turkey (Cakmak et al., 1999), and I fertilization in irrigation water in China (Xin-Min et al., 1997).Some other examples are increase in beta-carotene in orange-fleshed sweet potato has been observed with irrigation and chemical fertilizer treatments (Laurie et al., 2012).

In addition to fertilizers, plant growthpromoting soil microorganisms such as Bacillus, Pseudomonas, Rhizobium, Azotobacter, etc. can be utilized to increase the phytoavailability of mineral elements (Rengel et al., 1999, Smith and Read 2010). Nutrient mobility from soil to edible parts of plants helps to improve soil's nutritional status. The $\mathrm{N}_{2}$-fixing bacteria play important role in increasing crop productivity in nitrogen limited conditions (Sprent, 2004). Many crops are associated with mycorrhizal fungi that can release organic acids, and enzymes capable of degrading organic compounds subsequently increasing mineral concentrations in plant product (Rengel et al., 1999; Cavagnaro, 2008). Iron Biofortification of wheat grains has been accomplished through integrated use of organic and chemical fertilizers and zinc Biofortification by using Bacillus aryabhattai. Researchers improved the nutrient uptake and metabolic profile of sorghum and chickpea for iron and zinc by using the combination of plant growth-promoting bacteria and arbuscular mycorrhizal fungi (AMF) (Dhawi et al., 2015, 2016; Pellegrino and Bedini, 2014).

The inoculation of Azospirillum alone or in combination with phosphate-solubilizing bacteria increased sorghum grain yield and protein content by improving the status of phosphorous and nitrogen in the soil (Patidar and Mali 2004). Chickpea has been targeted for the mineral deficiencies, especially the mineral iron, zinc, calcium, copper, manganese, and $\mathrm{Mg}$ by using plant growthpromoting actinobacteria. Canola accompanied with plant growth-promoting rhizobacteria viz. Azospirillum brasilense, Azotobacter vinelandii along with chemical fertilizers resulted in increased protein, oleic acid, and linoleic acid content in the seed which indicated that rhizobacteria are highly effective in improving yield and nutrition of canola oil (Nosheen et al., 2011). To improve the human nutritional status various crops have been targeted through agronomical Biofortification approach.

\section{Biofortification: Conventional breeding approach}

Conventional breeding is capable of rising nutrient levels in staple crops required for 
improvement of human nutrition, without compromising yield and favorable agronomic traits. It is most accepted method of Biofortification as it offers a sustainable, economical approach alternative to transgenic and agronomic based strategies. Screening of germplasm for sufficient availability of genetic diversity, prebreeding of parental genotypes is necessary for conventional breeding to be achievable. During subsequent screening for parent, agronomic and plant type features are described. If variability is present in the strategic gene pool i.e. unadapted sources, pre-breeding is necessary prior to use of the trait, while if variation is present in the adapted gene pool, it can be directly used to develop new varieties. In this Biofortification approach, parent lines with high nutrients crossed with recipient line having desirable agronomic traits for many generations results with plant having desired nutrient and agronomic traits. Development of molecular markers helps to lower the costs and hasten the pace of breeding. After development of promising lines, they are tested in various locations across target environments to determine the genotype $\mathrm{x}$ environment interaction (GxE). The most desirable varieties are selected for multilocational, multi- seasonal testing by national research partners, and then submitted to government agencies for agronomic performance testing and release. As this approach is beneficial to improve plants, several international organizations have initiated various programs to improve the nutritional content of crops through breeding programs. The CGIAR along with the International Center for Tropical Agriculture (CIAT) and the International Food Policy Research Institute launched the Harvest Plus program to breed biofortified staple food crops. Due to more acceptability, huge numbers of crops have been targeted for Biofortification through crop breeding approach.
For examples, Old varieties of rice having high iron and zinc content and the higher mineral trait has been screened and combined with improved agronomic traits by breeding methods. In 2013, world's first zinc enriched rice varieties developed and released by HarvestPlus from Bangladesh Rice Research Institute (BRRIdhan 62, BRRIdhan72, and BRRIdhan 64), which is claimed to contain 20-22 ppm zinc in brown rice. An improved line(IR68144-3B-2-2-3) was identified from a cross between IR72*ZawaBonday showing high concentration of grain Fe i.e. about 21 ppm in brown rice (Gregorio et al., 2000). Similarly, a traditional variety named "jalmagan" has been identified containing double the iron concentration and $40 \%$ more $\mathrm{Zn}$ concentration compare to common rice variety for further breeding programs (Gregorio et al., 2000).In wheat, two varieties BHU 1 and BHU 6 have characterized with high yield, disease resistance in addition to high zinc. PBW1Zna wheat variety with high zinc has been released by Punjab Agricultural University, India. Apart from releasing varieties, several breeders have reported rise in the $\mathrm{Fe}$ and $\mathrm{Zn}$ content of wheat by plant breeding (Cakmak et al., 1999, Welch et al., 2005, Monasterio and Graham 2000, Çakmak et al., 2004). Pro-vitamin A has been also targeted for Biofortification through breeding approach, pro-vitamin A maize is one of the best example. Biofortified orange maize varieties have been grown commercially in Nigeria \{Ife maizehyb-3,4, Sammaz 38, 39 (OPV)\}, Zambia (GV662A, GV664A, and GV665A), and Ghana \{CSIR-CRI Honampa (OPV)\} since 2013 (300). In 2005, Indian Agricultural Research Institute (IARI) has released a high pro-vitamin A durum wheat variety named HI 8627. Biofortified iron rich sorghum lines (ICSR 14001, ICSH 14002) and hybrids (ICSA $661 \times$ ICSR 196, ICSA $318 \times$ ICSR 94, ICSA $336 \times$ IS 3760) and iron and zinc rich pearl millet variety "Dhanashakti" and a hybrid ICMH 1201 
(Shakti-1201) have been developed and released by ICRISAT. Similarly, Bio cassava Plus program had been introduced to advance the nutritional status of cassava crop. Cassava also has a wide range of genotypic differences for total carotene, proteins, and minerals which prove helpful for the development of improved cassava with high nutritive value (Maziya-Dixon et al., 2000, Chávez et al., 2005).Another example ofBiofortification through conventional breeding approach is tomato's anthocyaninrich deep purple fruit peel variety "Sun Black" (Smith et al., 2006).

\section{Biofortification: Transgenic approach}

Transgenic approach is best when the target nutrient does not exist naturally at the required level seven in germplasm banks i.e. limited or no genetic variability (Zhu et al., 2007, Brinch-Pedersen et al., 2007).The Key for development of transgenic crop relies on ability to identify, characterize and utilize these genes to engineer plant metabolism (Christou and Twyman 2004). It depends onunlimited genetic pool for the transfer and expression of desirable genes from one plant animal species to another either plant animal species which is independent of their evolutionary and taxonomic status (PérezMassot et al., 2007). Furthermore, besides genes pathways from bacteria and other organisms can also be introduced as metabolic engineering (Newell-McGloughlin, (2008). Transgenically fortified crops need substantial amount of time and investment during initial stage of development however in long run it is cost effective in nature (Hefferon, 2016; Guo, 2005). Other benefit has no taxonomic restraints and even synthetic genes can be used. Numerous examples of genetically modified crops are present having enhanced micronutrients.

Golden Rice was a significant revolutionas a high source of provitamin A (beta-carotene) with a high potential to reduce disease by expressing genes encoding $P S Y$ and carotene desaturase (Beyer et al., 2002, Datta et al., 2003, Paine et al., 2005, Burkhardt et al., 1997). Phytoene, beta-carotene precursor level has been boosted up to 23 -fold by targeting gene encoding carotene desaturase (Burkhardt et al., 1997). Despite being available as a prototype since early 2000, however, Golden Rice has not been introduced in any country, in large part due to highly risk-averse regulatory approval processes (Wesseler and Zilberman, 2014). While these transgenic varieties have tremendous nutritional potential, release to farmers is several years in the future, and depends on approval through national biosafety and regulatory processes. Similarly, in ricefolic acid (vitamin B9; which is important for normal pregnancy and anemia) has been increase as folate content (up to 150fold) by overexpressing genes encoding Arabidopsis GTP-cyclohydrolase I (GTPCHI) and aminodeoxychorismate synthase [ADCS (Storozhenko et al., 2007, Blancquaert et al., 2015, Bibbins-Domingo et al., 2007). Furthermore, $\mathrm{Zn}$ content was also elevated in GM rice by overexpressing OsIRT1 (Lee and An 2009) and mugineic acid synthesis genes from barley [HvNAS1, HvNAS1, HvNAAT-A, HvNAAT-B, IDS3, Masuda et al., 2008]. Transgenic iron and zinc rice has been developed and tested in confined field trials that can provide $30 \%$ of the EAR for both nutrients (Trijatmiko et al., 2016). In Case of wheat iron content has been boosted by expression of ferritin gene from soybean (Xiaoyan et al., 2012) and iron bioavailability increases by phytase activity by the expression of the phytochromegene [phyA(Brinch-Pedersen et al., 2000)] and phytic acid content has been decreased by silencing of wheat $\mathrm{ABCC} 13$ transporter (Bhati et al., 2006). Provitamin A (carotenoids) enriched maize endosperm has been developed by expressing bacterial $\operatorname{crtB}($ 
Aluru et al., 2008) and multiple (Khush et al., 2012) carotenogenic genes (Decourcelle et al., 2015, Zhu et al., 2008). Kim et al., (2012) has demonstrated the production of a high provitaminA (beta-carotene) soybean through overexpression of PSY and carotene desaturase. Another important nutrient vitamin $E$ activity in barley has been enhanced with increased content of $\delta$ tocopherol and decreased $\gamma$-tocopherolby coexpressing 2-methyl-6-phytyl benzoquinol methyltransferase genes [At-VTE3; At-VTE4 (Van Eenennaam et al., 2003)]. In tuber, Beta-carotene content has been improvedby using RNAi technique. Silencing of the betacarotene hydroxylase gene(bch), which converts beta-carotene to zeaxanthin (Van Eck et al., 2007) and by regulation of betacarotene synthesis through expression of lycopene $\beta$-cyclase [StLCYb(Song et al., 2016)] Betacarotene rich tuber has been developed. In another experiment, it has been observed that incorporation of $\mathrm{Or}$ gene from orange cauliflower mutant leads to increase in carotenoids along with three additional metabolite intermediates phytoene, phytofluene, and z-carotene (Lopez et al., 2008).InBioCassava Plus project, transgenic cassava developed that expresses betacarotene in roots using $n p t \mathrm{II}, \mathrm{crt} B$, and $D X S$. Transgenic cassava varieties biofortifed for improved levels of iron, beta-carotene, and zinc are under development and field trials in the BiocassavaPlusProgram targeted at African countries.

\section{Advantages, disadvantages and Limitations of biofortification}

Cost of conventional crop seeds and biofortified crops seeds are same, means no negative cost implications for farmers. However, there is small surplus income for predominantly subsistence farmers to improve living stander of their family. Seeds and cuttings and can easily be shared between farmers and used for many generations which make it sustainable and cost effective. Furthermore, surplus food produced by farmers can be sold and possibly reach more groups but any health benefits identified cannot be inferred to non-farming groups, where consumption of staple crops is likely to be lower. Even though biofortification needs a huge amount of investment at initial stage for breeding and testing of crop, cost-effective analysis has confirmed that biofortification is significantly inexpensive than either fortification or supplementation approaches. Some disadvantages and limitations are like success of agronomical biofortification is extremely in constant due to the differences in mineral mobility, mineral accumulation, and in soil compositions in different geographical location (Ismail et al., 2007). For example, a study including diverse rice genotypes showedthat, due to reduction in the root biomass differences in the phosphate uptake among the genotypes were as high as 20 -fold. (Wissuwa and Ae, 2001; White and Zasoski, 1999). Agronomic biofortification demands continuous inputs, through the application of micronutrient to the soil or plant regularly and make it uneconomical. Furthermore, it is not always surethat micronutrient is accumulating into edible plant parts like seed or fruit it sometimes can accumulate in leaves or other non-edible portions of plants; therefore, this method is successful only in certain minerals and specific plant species. For instance, higher zinc efficiency in cereals grown in zinc deficient soils in Turkey was associated with higher uptake of zinc from the soil, but not with increased accumulation of zinc in the grain (Cakmak et al., 1999). Furthermore, mineral bioavailability hindered by antinutrient compound like phytic acid and fertilizers accumulation in soil and water poses adverse environmental effects (Frossard et al., 2000, Waters and Sankaran 2011). Conventional Biofortification mainly face limitations for amount of genetic variability 
for the micronutrients in primary gene pool to overcome crossing with distant relatives and introgressing trait can be possible. However, breeding for a specific trait using conventional means took unrealistic timescale and effort, e.g., improving Se concentration in wheat grains (Lyons et al., 2005) and improvement of oleic, linoleic, and linolenic fatty acid content in soybean (Oliva et al., 2006). In general, improvement in oil quality has been targeted with better results with transgenic-based approach due to limited variability, heritability, and linkage drag but major limitation of transgenic method is its low acceptance among masses (Al-Babili and Beyer 2005). Unfortunately, the current political and economic landscape which plays an important role in its acceptance is not open to this technology (Inaba and Macer 2004, Watanabe et al., 2005). Let us take the example of Bt Brinjal, developed by Mahyco, an Indian seed company which was not released in India because some of the scientists, farmers, and anti-GMO activists and raised concerns againt it. However, in other countries like Bangladesh were given approval for four varieties of $\mathrm{Bt}$ Brinjal in 2013-2014. In transgenic-based approach, its success rate in terms of cultivar release to research efforts is very low due to time required from target trait and gene identification, modification, expression, and assessment of agronomical traits to understanding the possible effect on other life forms. For example, the Golden rice Concept were first published in Science in 2000 (Beyer et al., 2002), and since then different groups, including International Rice Research Institute scientists are working on it, but Golden Rice is still not ready for farmers due to issues with its yield and government approval for its dissemination. Another consideration is postharvest processing of each biofortified crops. For example, the seeds of many cereals are often consumed after milling or polishing as concentrations of some essential mineral elements, such as iron, zinc, and copper, are highest in the bran (Gregorio et al., 2000, Waters and Sankaran 2011) which may remove from diet due milling or polishing cereal seeds and the extent of these losses is genotype dependent (Gregorio et al., 2000). In addition, the presence of certain antinutrientslike phytate, tannins, oxalate, fiber, and hemaglutinins reduce the bioavailability of minerals in human gut (Holme et al., 2012). Furthermore, in the context of global environmental change, approaches for improving food production improvements in a crop's ability to maintain yields with lower water supply and quality will be critical. In addition, numerous genes are involved in controlling the amount of a mineral element that is absorbed by roots, translocated to shoot, remobilized from vegetative tissues, and deposited in edible portions of seeds and grains in forms that are utilizable in persons consuming the crop (Welch 1986, Welch and Shuman 1995, Haas et al., 2005).

In conclusion, it is strongly recognized that biofortification is anauspicious, economical, sustainable agricultural strategy for improving the nutritional status of malnourished populations throughout the world. Biofortification strategies based on different approaches like crop breeding, targeted genetic manipulation and the application of mineral fertilizers hold great potential for addressing mineral malnutrition in humans. Biofortified food crops with increases in iron, zinc, Se, and provitamin A content are providing sufficient levels of these micronutrients in the diets of the developing and developed world where it was previously lacking. International initiatives, such as the HarvestPlus program and national initiatives, are acting as pillars to achieve these targets. These efforts have delivered crops with the potential to increase both the amounts and bioavailability of essential mineral elements 
in human diets, especially in staple cereal crops like wheat, maize, cassava, beans, sweet potatoes, and millets. But biofortification of crops is a challenging endeavor. To achieve this, collaboration between plant breeders, nutrition scientists, genetic engineers, and molecular biologists is essential. Traditional breeding approaches are finding widespread and easy acceptance and have been used to enhance the nutritional qualities of foods. Although a greater emphasis is being laid on transgenic means success rates of breeding based approaches are much higher as transgenically fortified crop plants have to face hurdles due to acceptance constraints among consumers and different expensive and time consuming regulatory approval processes, adopted by different countries. Besides the challenges, biofortified crops hold a very bright future as these have the potential to remove micronutrient malnutrition among billions of poor people, especially in the developing countries.

\section{References}

Agrawal, P. K., Kohli, A., Twyman, R. M., and Christou, P. (2005). Transformation of plants with multiple cassettes generates simple transgene integration patterns and high expression levels. Molecular Breeding, 16(3), 247-260.

Al-Babili, S., and Beyer, P. (2005). Golden Ricefive years on the road-five years to go? Trends in plant science, 10(12), 565-573.

Aluru, M., Xu, Y., Guo, R., Wang, Z., Li, S., White, W. and Rodermel, S. (2008). Generation of transgenic maize with enhanced provitamin A content. Journal of experimental Botany, 59(13), 3551-3562.

Aro, A., Alfthan, G., and Varo, P. (1995). Effects of supplementation of fertilizers on human selenium status in Finland. Analyst, 120(3), 841-843.

Asare-Marfo, D., Birol, E., Gonzalez, C., Moursi, M., Perez, S., Schwarz, J., and Zeller, M. (2013).Prioritizing countries for biofortification interventions using country- level data. International Food Policy Research Institute (IFPRI).

Beyer, P., Al-Babili, S., Ye, X., Lucca, P., Schaub, P., Welsch, R., and Potrykus, I. (2002). Golden rice: Introducing the $\beta$ carotene biosynthesis pathway into rice endosperm by genetic engineering to defeat vitamin A deficiency. The Journal of nutrition, 132(3), 506S-510S.

Beyer, P., Al-Babili, S., Ye, X., Lucca, P., Schaub, P., Welsch, R., and Potrykus, I. (2002). Golden rice: Introducing the $\beta$ carotene biosynthesis pathway into rice endosperm by genetic engineering to defeat vitamin A deficiency. The Journal of nutrition, 132(3), 506S-510S.

Bhati, K. K., Alok, A., Kumar, A., Kaur, J., Tiwari, S., and Pandey, A. K. (2016). Silencing of ABCC13 transporter in wheat reveals its involvement in grain development, phytic acid accumulation and lateral root formation. Journal of experimental botany, 67(14), 4379-4389.

Bibbins-Domingo, K., Grossman, D. C., Curry, S. J., Davidson, K. W., Epling, J. W., García, F. A and Mangione, C. M. (2017). Folic acid supplementation for the prevention of neural tube defects: US Preventive Services Task Force recommendation statement. Jama, 317(2), 183-189.

Blancquaert, D., Van Daele, J., Strobbe, S., Kiekens, F., Storozhenko, S., De Steur, H. and Van Der Straeten, D. (2015). Improving folate (vitamin B 9) stability in biofortified rice through metabolic engineering. Nature Biotechnology, 33(10), 1076.

Boonchuay, P., Cakmak, I., Rerkasem, B., and Prom-U-Thai, C. (2013). Effect of different foliar zinc application at different growth stages on seed zinc concentration and its impact on seedling vigor in rice. Soil science and plant nutrition, 59(2), 180-188.

Bouis, H. E. (1999). Economics of enhanced micronutrient density in food staples. Field Crops Research, 60(1-2), 165-173.

Bouis, H. E., Hotz, C., McClafferty, B., Meenakshi, J. V., and Pfeiffer, W. H. (2011).Biofortification: a new tool to reduce micronutrient malnutrition. Food and nutrition bulletin, 32(1_suppl1), S31- 
S40.

Branca, F., and Ferrari, M. (2002). Impact of micronutrient deficiencies on growth: the stunting syndrome. Annals of Nutrition and Metabolism, 46(Suppl. 1), 8-17.

Brinch-Pedersen, H., Borg, S., Tauris, B., and Holm, P. B. (2007). Molecular genetic approaches to increasing mineral availability and vitamin content of cereals. Journal of Cereal Science, 46(3), 308-326.

Brinch-Pedersen, H., Borg, S., Tauris, B., and Holm, P. B. (2007). Molecular genetic approaches to increasing mineral availability and vitamin content of cereals. Journal of Cereal Science, 46(3), 308-326.

Brinch-Pedersen, H., Olesen, A., Rasmussen, S. K., and Holm, P. B. (2000).Generation of transgenic wheat (Triticum aestivum L.) for constitutive accumulation of an Aspergillus phytase. Molecular Breeding, 6(2), 195206.

Burkhardt, P. K., Beyer, P., Wünn, J., Klöti, A., Armstrong, G. A., Schledz, M. and Potrykus, I. (1997). Transgenic rice (Oryza sativa) endosperm expressing daffodil (Narcissus pseudonarcissus) phytoene synthase accumulates phytoene, a key intermediate of provitamin A biosynthesis. The Plant Journal, 11(5), 1071-1078.

Caballero, B. (2002). Global patterns of child health: the role of nutrition. Annals of Nutrition and Metabolism, 46(Suppl. 1), 37.

Cakmak, I. (2008). Enrichment of cereal grains with zinc: agronomic or genetic biofortification?. Plant and soil, 302(1-2), 1-17.

Cakmak, I., and Kutman, U. B. (2018). Agronomic biofortification of cereals with zinc: a review. European Journal of Soil Science, 69(1), 172-180.

Cakmak, I., Kalayc1, M., Ekiz, H., Braun, H. J., Kılınç, Y., and Yılmaz, A. (1999). Zinc deficiency as a practical problem in plant and human nutrition in Turkey: a NATOscience for stability project. Field Crops Research, 60(1-2), 175-188.

Cakmak, I., Kalayc1, M., Ekiz, H., Braun, H. J., Kilınç, Y., and Yılmaz, A. (1999). Zinc deficiency as a practical problem in plant and human nutrition in Turkey: a NATO- science for stability project. Field Crops Research, 60(1-2), 175-188.

Cakmak, I., Kalaycı, M., Ekiz, H., Braun, H. J., Kılınç, Y., and Yilmaz, A. (1999). Zinc deficiency as a practical problem in plant and human nutrition in Turkey: a NATOscience for stability project. Field Crops Research, 60(1-2), 175-188.

Çakmak, İ., Torun, A., Millet, E., Feldman, M., Fahima, T., Korol, A and Özkan, H. (2004). Triticum dicoccoides: an important genetic resource for increasing zinc and iron concentration in modern cultivated wheat. Soil science and plant nutrition, 50(7), 1047-1054.

Cavagnaro, T. R. (2008). The role of arbuscular mycorrhizas in improving plant zinc nutrition under low soil zinc concentrations: a review. Plant and Soil, 304(1-2), 315325 .

Chávez, A. L., Sánchez, T., Jaramillo, G., Bedoya, J., Echeverry, J., Bolaños, E. A. and Iglesias, C. A. (2005). Variation of quality traits in cassava roots evaluated in landraces and improved clones. Euphytica, 143(1-2), 125-133.

Chen, L., Yang, F., Xu, J., Hu, Y., Hu, Q., Zhang, Y., and Pan, G. (2002).Determination of selenium concentration of rice in China and effect of fertilization of selenite and selenate on selenium content of rice. Journal of Agricultural and Food Chemistry, 50(18), 5128-5130.

Christou, P., and Twyman, R. M. (2004).The potential of genetically enhanced plants to address food insecurity. Nutrition research reviews, 17(1), 23-42.

Cuderman, P., Kreft, I., Germ, M., Kovačevič, M., and Stibilj, V. (2008). Selenium species in selenium-enriched and drought-exposed potatoes. Journal of agricultural and food chemistry, 56(19), 9114-9120.

Daniels, L. A. (1996). Selenium metabolism and bioavailability. Biological trace element research, 54(3), 185-199.

Datta, K., Baisakh, N., Oliva, N., Torrizo, L., Abrigo, E., Tan, J. and Potrykus, I. (2003).Bioengineered 'golden' indica rice cultivars with $\beta$ - carotene metabolism in the endosperm with hygromycin and mannose selection systems. Plant 
Biotechnology Journal, 1(2), 81-90.

Decourcelle, M., Perez-Fons, L., Baulande, S., Steiger, S., Couvelard, L., Hem, S. and Sandmann, G. (2015). Combined transcript, proteome, and metabolite analysis of transgenic maize seeds engineered for enhanced carotenoid synthesis reveals pleotropic effects in core metabolism. Journal of experimental botany, 66(11), 3141-3150.

Dhawi, F., Datta, R., and Ramakrishna, W. (2015). Mycorrhiza and PGPB modulate maize biomass, nutrient uptake and metabolic pathways in maize grown in mining-impacted soil. Plant Physiology and Biochemistry, 97, 390-399.

Dhawi, F., Datta, R., and Ramakrishna, W. (2016). Mycorrhiza and heavy metal resistant bacteria enhance growth, nutrient uptake and alter metabolic profile of sorghum grown in marginal soil. Chemosphere, 157, 33-41.

Fang, Y., Wang, L., Xin, Z., Zhao, L., An, X., and $\mathrm{Hu}$, Q. (2008). Effect of foliar application of zinc, selenium, and iron fertilizers on nutrients concentration and yield of rice grain in China. Journal of Agricultural and Food Chemistry, 56(6), 2079-2084.

FAO, IFAD, WFP, 2015. The State of Food Insecurity in the World 2015. FAO, Rome. Finkelstein, J., Mehta, S., Udipi, S., et al., 2015. A randomized trial of ironbiofortified pearl millet in school children in India. J. Nutr., http://dx.doi.org/10.3945/jn.114.208009

Frossard, E., Bucher, M., Mächler, F., Mozafar, A., and Hurrell, R. (2000). Potential for increasing the content and bioavailability of $\mathrm{Fe}, \mathrm{Zn}$ and $\mathrm{Ca}$ in plants for human nutrition. Journal of the Science of Food and Agriculture, 80(7), 861-879.

Gannon, B., Kaliwile, C., Arscott, S. A., Schmaelzle, S., Chileshe, J., Kalungwana, $\mathrm{N}$ and Tanumihardjo, S. A. (2014). Biofortified orange maize is as efficacious as a vitamin A supplement in Zambian children even in the presence of high liver reserves of vitamin A: a community-based, randomized placebo-controlled trial. The American journal of clinical nutrition, 100(6), 1541-1550.
Giacosa, A., Faliva, M., Perna, S., Minoia, C., Ronchi, A., and Rondanelli, M. (2014). Selenium fortification of an Italian rice cultivar via foliar fertilization with sodium selenate and its effects on human serum selenium levels and on erythrocyte glutathione peroxidase activity. Nutrients, 6(3), 1251-1261.

Gilani, G. S., and Nasim, A. (2007). Impact of foods nutritionally enhanced through biotechnology in alleviating malnutrition in developing countries. Journal of AOAC International, 90(5), 1440-1444.

Golden, M. H. (1991). The nature of nutritional deficiency in relation to growth failure and poverty. ActaPaediatrica, 80, 95-110.

Gould, J. (2017). Nutrition: A world of insecurity. Nature, 544(7651), S6-S6.

Graham, R. D., Welch, R. M., and Bouis, H. E. (2001). Addressing micronutrient malnutrition through enhancing the nutritional quality of staple foods: principles, perspectives and knowledge gaps.

Grantham-McGregor, S. M., and Ani, C. C. (1999).The role of micronutrients in psychomotor and cognitive development. British Medical Bulletin, 55(3), 511-527.

Gregorio, G. B., Senadhira, D., Htut, H., and Graham, R. D. (2000). Breeding for trace mineral density in rice. Food and Nutrition Bulletin, 21(4), 382-386.

Gregorio, G. B., Senadhira, D., Htut, H., and Graham, R. D. (2000). Breeding for trace mineral density in rice. Food and Nutrition Bulletin, 21(4), 382-386.

Guo, W. Z., Zhang, T. Z., Ding, Y. Z., Zhu, Y. C., Shen, X. L., and Zhu, X. F. (2005). Molecular marker assisted selection and pyramiding of two QTLs for fiber strength in upland cotton. Yi chuanxuebao= Actagenetica Sinica, 32(12), 1275-1285.

Guo, W. Z., Zhang, T. Z., Ding, Y. Z., Zhu, Y. C., Shen, X. L., and Zhu, X. F. (2005). Molecular marker assisted selection and pyramiding of two QTLs for fiber strength in upland cotton. Yi chuanxuebao= Actagenetica Sinica, 32(12), 1275-1285.

Haas, J. D., Beard, J. L., Murray-Kolb, L. E., Del Mundo, A. M., Felix, A., and Gregorio, G. B. (2005). Iron-biofortified rice improves 
the iron stores of nonanemic Filipino women. The Journal of nutrition, 135(12), 2823-2830.

Haas, J., Luna, S. V., Lung'aho, M. G., Ngabo, F., Wenger, M., Murray-Kolb and Egli, I. (2017). Consuming iron biofortified beans significantly improved iron status in Rwandan women after 18 weeks. J. Nutr. http://dx. doi. org/10.3945/jn, 115.

Hamidou, F., Rathore, A., Waliyar, F., and Vadez, V. (2014). Although drought intensity increases aflatoxin contamination, drought tolerance does not lead to less aflatoxin contamination. Field Crops Research, 156, 103-110.

Haskell, M. J., Jamil, K. M., Hassan, F., Peerson, J. M., Hossain, M. I., Fuchs, G. J., and Brown, K. H. (2004). Daily consumption of Indian spinach (Basella alba) or sweet potatoes has a positive effect on total-body vitamin A stores in Bangladeshi men. The American journal of clinical nutrition, 80(3), 705-714.

He, W., Shohag, M. J. I., Wei, Y., Feng, Y., and Yang, X. (2013). Iron concentration, bioavailability, and nutritional quality of polished rice affected by different forms of foliar iron fertilizer. Food chemistry, 141(4), 4122-4126.

Hefferon, K. L. (2016). Can biofortified crops help attain food security?. Current Molecular Biology Reports, 2(4), 180-185.

Hodge J. Hidden hunger: approaches to tackling micronutrient defciencies.In: Gillespie S, Hodge J, Yosef S, Pandya-Lorch R, editors. Nourishing Millions: Stories of Change in Nutrition. Washington: International FoodPolicy Research Institute (IFPRI) (2016). p. 35-43.

Holme, I. B., Dionisio, G., Brinch- Pedersen, H., Wendt, T., Madsen, C. K., Vincze, E., and Holm, P. B. (2012).Cisgenic barley with improved phytase activity. Plant biotechnology journal, 10(2), 237-247.

Hotz, C., Loechl, C., de Brauw, A., Eozenou, P., Gilligan, D., Moursi, and Meenakshi, J. V. (2012). A large-scale intervention to introduce orange sweet potato in rural Mozambique increases vitamin A intakes among children and women. British Journal of Nutrition, 108(1), 163-176.
Inaba, M., and Macer, D. (2004).Policy, regulation and attitudes towards agricultural biotechnology in Japan. Journal of International Biotechnology Law, 1(2), 4553.

Ismail, A. M., Heuer, S., Thomson, M. J., and Wissuwa, M. (2007). Genetic and genomic approaches to develop rice germplasm for problem soils. Plant molecular biology, 65(4), 547-570.

Jiang, W., Struik, P. C., Van Keulen, H., Zhao, M., Jin, L. N., and Stomph, T. J. (2008). Does increased zinc uptake enhance grain zinc mass concentration in rice? Annals of Applied Biology, 153(1), 135-147.

Khush, G. S., Lee, S., Cho, J. I., and Jeon, J. S. (2012). Biofortification of crops for reducing malnutrition. Plant biotechnology reports, 6(3), 195-202.

Khush, G. S., Lee, S., Cho, J. I., and Jeon, J. S. (2012). Biofortification of crops for reducing malnutrition. Plant biotechnology reports, 6(3), 195-202.

Kim, M. J., Kim, J. K., Kim, H. J., Pak, J. H., Lee, J. H., Kim, D. H and Ha, S. H. (2012). Genetic modification of the soybean to enhance the $\beta$-carotene content through seed-specific expression. PLoS One, 7(10), e48287.

King, J. C., Brown, K. H., Gibson, R. S., Krebs, N. F., Lowe, N. M., Siekmann, J. H., and Raiten, D. J. (2015). Biomarkers of Nutrition for Development (BOND) - zinc review. The Journal of nutrition, 146(4), $858 \mathrm{~S}-885 \mathrm{~S}$.

Laurie, S. M., Faber, M., Van Jaarsveld, P. J., Laurie, R. N., Du Plooy, C. P., and Modisane, P. C. (2012). $\beta$-Carotene yield and productivity of orange-fleshed sweet potato (Ipomoea batatas L. Lam.) as influenced by irrigation and fertilizer application treatments. Scientia horticulturae, 142, 180-184.

Lee, S., and An, G. (2009). Over- expression of OsIRT1 leads to increased iron and zinc accumulations in rice. Plant, Cell and Environment, 32(4), 408-416.

Liu, K., and Gu, Z. (2008). Selenium accumulation in different brown rice cultivars and its distribution in fractions. Journal of agricultural and food chemistry, 
57(2), 695-700.

Lopez, A. B., Van Eck, J., Conlin, B. J., Paolillo, D. J., O'neill, J., and Li, L. (2008). Effect of the cauliflower Or transgene on carotenoid accumulation and chromoplast formation in transgenic potato tubers. Journal of Experimental Botany, 59(2), 213-223.

Low, J. W., Arimond, M., Osman, N., Cunguara, B., Zano, F., and Tschirley, D. (2007). A food-based approach introducing orangefleshed sweet potatoes increased vitamin A intake and serum retinol concentrations in young children in rural Mozambique. The Journal of nutrition, 137(5), 1320-1327.

Lyons, G., Ortiz-Monasterio, I., Stangoulis, J., and Graham, R. (2005). Selenium concentration in wheat grain: is there sufficient genotypic variation to use in breeding?. Plant and Soil, 269(1-2), 369380 .

Masuda, H., Suzuki, M., Morikawa, K. C., Kobayashi, T., Nakanishi, H., Takahashi, M. and Nishizawa, N. K. (2008). Increase in iron and zinc concentrations in rice grains via the introduction of barley genes involved in phytosiderophore synthesis. Rice, 1(1), 100-108.

Maziya-Dixon, B., Kling, J. G., Menkir, A., and Dixon, A. (2000). Genetic variation in total carotene, iron, and zinc contents of maize and cassava genotypes. Food and Nutrition Bulletin, 21(4), 419-422.

McGuire, J. (1993). Addressing micronutrient malnutrition. Scn News, 9, 1-10.

Monasterio, I., and Graham, R. D. (2000). Breeding for trace minerals in wheat. Food and Nutrition Bulletin, 21(4), 392-396.

Nestel, P., Bouis, H. E., Meenakshi, J. V., and Pfeiffer, W. (2006). Biofortification of staple food crops. The Journal of nutrition, 136(4), 1064-1067.

Newell-McGloughlin, M. (2008). Nutritionally improved agricultural crops. Plant Physiology, 147(3), 939-953.

Newell-McGloughlin, M. (2008). Nutritionally improved agricultural crops. Plant Physiology, 147(3), 939-953.

Nishida, C., Shetty, P., and Uauy, R. (2004). Diet, nutrition and the prevention of chronic diseases: scientific background papers of the Joint WHO/FAO Expert Consultation
(Geneva, 28 January-1 February 2002)Introduction. Public health nutrition, 7(1), 99-100.

Nosheen, A., Bano, A., and Ullah, F. (2011). Nutritive value of canola (Brassica napus L.) as affected by plant growth promoting rhizobacteria. European Journal of Lipid Science and Technology, 113(11), 13421346.

Oliva, M. L., Shannon, J. G., Sleper, D. A., Ellersieck, M. R., Cardinal, A. J., Paris, R. L., and Lee, J. D. (2006). Stability of fatty acid profile in soybean genotypes with modified seed oil composition. Crop Science, 46(5), 2069-2075.

Paine, J. A., Shipton, C. A., Chaggar, S., Howells, R. M., Kennedy, M. J., Vernon, G. and Drake, R. (2005). Improving the nutritional value of Golden Rice through increased pro-vitamin A content. Nature biotechnology, 23(4), 482.

Palmer, A. C., Healy, K., Barffour, M. A., Siamusantu, W., Chileshe, J., Schulze, K. J and Labrique, A. B. (2016). Provitamin A carotenoid-biofortified maize consumption increases pupillary responsiveness among Zambian children in a randomized controlled trial. The Journal of nutrition, 146(12), 2551-2558.

Patidar, M., and Mali, A. L. (2004).Effect of farmyard manure, fertility levels and biofertilizers on growth, yield and quality of sorghum (Sorghum bicolor). Indian Journal of Agronomy, 49(2), 117-120.

Pellegrino, E., and Bedini, S. (2014). Enhancing ecosystem services in sustainable agriculture: biofertilization and biofortification of chickpea (Cicer arietinum L.) by arbuscular mycorrhizal fungi. Soil Biology and biochemistry, 68, 429-439.

Pérez-Massot, E., Banakar, R., Gómez-Galera, S., Zorrilla-López, U., Sanahuja, G., Arjó, G. and Dashevskaya, S. (2013). The contribution of transgenic plants to better health through improved nutrition: opportunities and constraints. Genes and nutrition, 8(1), 29-41.

Pfeiffer, W. H., and McClafferty, B. (2007). Harvest Plus: breeding crops for better nutrition. Crop Science, 47(Supplement_3), 
S-88.

Pingali, P. L. (2012). Green revolution: impacts, limits, and the path ahead. Proceedings of the National Academy of Sciences, 109(31), 12302-12308.

Poggi, V., Arcioni, A., Filippini, P., and Pifferi, P. G. (2000). Foliar application of selenite and selenate to potato (Solanum tuberosum): Effect of a ligand agent on selenium content of tubers. Journal of agricultural and food chemistry, 48(10), 4749-4751.

Prashanth, L., Kattapagari, K. K., Chitturi, R. T., Baddam, V. R. R., and Prasad, L. K. (2015). A review on role of essential trace elements in health and disease. Journal of $d r$. ntr university of health sciences, 4(2), 75 .

Premarathna, L., McLaughlin, M. J., Kirby, J. K., Hettiarachchi, G. M., Stacey, S., and Chittleborough, D. J. (2012). Selenateenriched urea granules are a highly effective fertilizer for selenium biofortification of paddy rice grain. Journal of agricultural and food chemistry, 60(23), 6037-6044.

Ram, H., Rashid, A., Zhang, W., Duarte, A. P., Phattarakul, N., Simunji, S and Mahmood, K. (2016). Biofortification of wheat, rice and common bean by applying foliar zinc fertilizer along with pesticides in seven countries. Plant and Soil, 403(1-2), 389401.

Ramakrishnam, U., Manjrekrar, R., Rivera, J., Gonzales-Cossio, T., and Martorell, R. (1999). Micronutrients and pregnancy outcomes: a review of the literature. Nutr Res, 19, 103-159.

Rengel, Z., Batten, G. D., and Crowley, D. D. (1999). Agronomic approaches for improving the micronutrient density in edible portions of field crops. Field crops research, 60(1-2), 27-40.

Ros, G. H., Van Rotterdam, A. M. D., Bussink, D. W., and Bindraban, P. S. (2016). Selenium fertilization strategies for bio-fortification of food: an agro-ecosystem approach. Plant and soil, 404(1-2), 99-112.

Rosado, J. L., Hambidge, K. M., Miller, L. V., Garcia, O. P., Westcott, J., Gonzalez, K and Krebs, N. F. (2009). The quantity of zinc absorbed from wheat in adult women is enhanced by biofortification. The Journal of nutrition, 139(10), 1920-1925.

Rudkowska, I., Jacques, H., Weisnagel, S. J., Marette, A., and Vohl, M. C. (2013).Transcriptomic profiles of skeletal muscle tissue following aneuglycemichyperinsulinemic clamp in insulin-resistant obese subjects. Genes and nutrition, 8(1), 91.

Saltzman, A., Birol, E., Bouis, H. E., Boy, E., De Moura, F. F., Islam, Y., and Pfeiffer, W. H. (2013). Biofortification: progress toward a more nourishing future. Glob Food Sec 2: 9-17.

Schneeman, B. O. (2001). Linking agricultural production and human nutrition. Journal of the Science of Food and Agriculture, 81(1), 3-9.

Shewmaker, C. K., Sheehy, J. A., Daley, M., Colburn, S., and Ke, D. Y. (1999). Seed- specific overexpression of phytoene synthase: increase in carotenoids and other metabolic effects. The Plant Journal, 20(4), 401-412.

Shivay, Y. S., Kumar, D., Prasad, R., and Ahlawat, I. P. S. (2008). Relative yield and zinc uptake by rice from zinc sulphate and zinc oxide coatings onto urea. Nutrient Cycling in Agroecosystems, 80(2), 181-188.

Smith, A. D., Crippa, A., Woodcock, J., and Brage, S. (2016). Physical activity and incident type 2 diabetes mellitus: a systematic review and dose-response metaanalysis of prospective cohort studies.

Smith, S. E., and Read, D. J. (2010). Mycorrhizal symbiosis. Academic press.

Smoleń, S., Kowalska, I., and Sady, W. (2014).Assessment of biofortification with iodine and selenium of lettuce cultivated in the NFT hydroponic system. Scientia Horticulturae, 166, 9-16.

Song, X. Y., Zhu, W. J., Tang, R. M., Cai, J. H., Chen, M., and Yang, Q. (2016). Overexpression of StLCYb increases $\beta$-carotene accumulation in potato tubers. Plant Biotechnology Reports, 10(2), 95-104.

Sprent, J. I. (2004). Hardarson, G. and Broughton, WJ Maximising the use of biological nitrogen fixation in agriculture.

Stevens, G. A., Finucane, M. M., De-Regil, L. M., Paciorek, C. J., Flaxman, S. R., and Branca, 
F. Nutrition Impact Model Study Group. (2013). Global, regional, and national trends in haemoglobin concentration and prevalence of total and severe anaemia in children and pregnant and non-pregnant women for 1995-2011: a systematic analysis of population-representative data. The Lancet Global Health, 1(1), e16-e25.

Storozhenko, S., De Brouwer, V., Volckaert, M., Navarrete, O., Blancquaert, D., Zhang, G. F. and Van Der Straeten, D. (2007). Folate fortification of rice by metabolic engineering. Nature biotechnology, 25(11), 1277.

Sumithra, M., Jee Hyun, R., Jonathan, D. S., Franz, F. R., Klaus, K., and Robert, E. B. (2013). The global hidden hunger indices and maps: an advocacy tool for action.(research article). PLoS One, 8(6), e67860.

Van Eck, J., Conlin, B., Garvin, D. F., Mason, H., Navarre, D. A., and Brown, C. R. (2007). Enhancing beta-carotene content in potato by RNAi-mediated silencing of the betacarotene hydroxylase gene. American Journal of Potato Research, 84(4), 331.

Van Eenennaam, A. L., Lincoln, K., Durrett, T. P., Valentin, H. E., Shewmaker, C. K., Thorne, G. M. and Hao, M. (2003). Engineering vitamin $\mathrm{E}$ content: from Arabidopsis mutant to soy oil. The Plant Cell, 15(12), 3007-3019.

vanJaarsveld, P. J., Faber, M., Tanumihardjo, S. A., Nestel, P., Lombard, C. J., and Benadé, A. J. S. (2005). $\beta$-Carotene-rich orangefleshed sweet potato improves the vitamin A status of primary school children assessed with the modified-relative-doseresponse test. The American journal of clinical nutrition, 81(5), 1080-1087.

Watanabe, K. N., Sassa, Y., Suda, E., Chen, C. H., Inaba, M., and Kikuchi, A. (2005).Global political, economic, social and technological issues on trasnsgenic crops. Plant biotechnology, 22(5), 515-522.

Waters, B. M., and Sankaran, R. P. (2011). Moving micronutrients from the soil to the seeds: genes and physiological processes from a biofortification perspective. Plant Science, 180(4), 562-574.

Wei, Y., Shohag, M. J. I., and Yang, X.
(2012).Biofortification and bioavailability of rice grain zinc as affected by different forms of foliar zinc fertilization. PloS one, 7(9), e45428.

Welch, R. M. (1986). Effects of nutrient deficiencies on seed production and quality. Adv. Plant Nutr., 2, 205-247.

Welch, R. M., and Graham, R. D. (2004). Breeding for micronutrients in staple food crops from a human nutrition perspective. Journal of experimental botany, 55(396), 353-364.

Welch, R. M., and Shuman, L. (1995). Micronutrient nutrition of plants. Critical Reviews in plant sciences, 14(1), 49-82.

Welch, R. M., House, W. A., Ortiz-Monasterio, I., and Cheng, Z. (2005). Potential for improving bioavailable zinc in wheat grain (Triticum species) through plant breeding. Journal of agricultural and food chemistry, 53(6), 2176-2180.

White, J. G., and Zasoski, R. J. (1999). Mapping soil micronutrients. Field crops research, 60(1-2), 11-26.

White, P. J., Thompson, J. A., Wright, G., and Rasmussen, S. K. (2017). Biofortifying Scottish potatoes with zinc. Plant and soil, 411(1-2), 151-165.

Wissuwa, M., and Ae, N. (2001). Genotypic variation for tolerance to phosphorus deficiency in rice and the potential for its exploitation in rice improvement. Plant breeding, 120(1), 43-48.

Xiaoyan, S., Yan, Z., and Shubin, W. (2012). Improvement $\mathrm{Fe}$ content of wheat (Triticum aestivum) grain by soybean ferritin expression cassette without vector backbone sequence. Journal of Agricultural Biotechnology.

Xin-Min, J., Xue-Yi, C., Ji-Yong, J., Tai, M., James, D. W., Rakeman, M. A. and Delong, G. R. (1997). Dynamics of environmental supplementation of iodine: four years' experience of iodination of irrigation water in Hotien, Xinjiang, China. Archives of Environmental Health: An International Journal, 52(6), 399-408.

$\mathrm{Xu}$, J., and $\mathrm{Hu}, \mathrm{Q}$. (2004). Effect of foliar application of selenium on the antioxidant activity of aqueous and ethanolic extracts of selenium-enriched rice. Journal of 
agricultural and food chemistry, 52(6), 1759-1763.

Yang, F., Chen, L., Hu, Q., and Pan, G. (2003). Effect of the application of selenium on selenium content of soybean and its products. Biological Trace Element Research, 93(1-3), 249-256.

Yang, S. H., Moran, D. L., Jia, H. W., Bicar, E. H., Lee, M., and Scott, M. P. (2002). Expression of a synthetic porcine $\alpha$ lactalbumin gene in the kernels of transgenic maize. Transgenic research, 11(1), 11-20.

Yang, X. W., Tian, X. H., Lu, X. C., Cao, Y. X., and Chen, Z. H. (2011). Impacts of phosphorus and zinc levels on phosphorus and zinc nutrition and phytic acid concentration in wheat (Triticum aestivum L.). Journal of the Science of Food and Agriculture, 91(13), 2322-2328.

Yoon, P. W., Olney, R. S., Khoury, M. J., Sappenfield, W. M., Chavez, G. F., and Taylor, D. (1997). Contribution of birth defects and genetic diseases to pediatric hospitalizations: a population-based study.
Archives of pediatrics and adolescent medicine, 151(11), 1096-1103.

Yuan, L., Wu, L., Yang, C., and Lv, Q. (2013). Effects of iron and zinc foliar applications on rice plants and their grain accumulation and grain nutritional quality. Journal of the Science of Food and Agriculture, 93(2), 254-261.

Zhu, C., Naqvi, S., Breitenbach, J., Sandmann, G., Christou, P., and Capell, T. (2008). Combinatorial genetic transformation generates a library of metabolic phenotypes for the carotenoid pathway in maize. Proceedings of the National Academy of Sciences, 105(47), 18232-18237.

Zhu, C., Naqvi, S., Gomez-Galera, S., Pelacho, A. M., Capell, T., and Christou, P. (2007). Transgenic strategies for the nutritional enhancement of plants. Trends in plant science, 12(12), 548-555.

Zhu, C., Naqvi, S., Gomez-Galera, S., Pelacho, A. M., Capell, T., and Christou, P. (2007). Transgenic strategies for the nutritional enhancement of plants. Trends in plant science, 12(12).

\section{How to cite this article:}

Neha Agrawal, Priyanka Upadhyay and Santosh B. Tigadi. 2020. Biofortification to Improve Nutrition: A Review. Int.J.Curr.Microbiol.App.Sci. 9(01): 763-779. doi: https://doi.org/10.20546/ijcmas.2020.901.083 